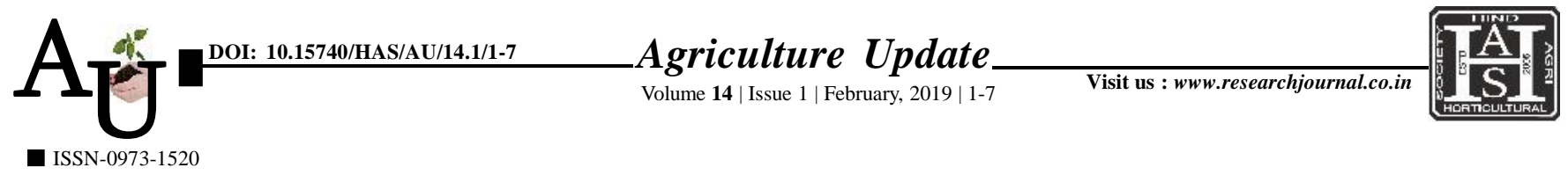

\title{
Research article: A study on home environment among rural, tribal and urban pre-school children
}

\section{S. Nayak and L. Pujar}

Article Chronicle: Received :

02.09.2018;

Revised :

25.12.2018;

Accepted :

01.01 .2019

KEY Words:

Children, Preschool, Home environment Hind Agri-Horticultural Society.
SUMMARY : A study on concept development among pre-school children was carried out in Ranebennur Taluk of Haveri district, Karnataka state. The sample for the study comprised of 120 pre-school children, of whom 40 were from rural, 40 from tribal and 40 from urban areas of Ranebennur Taluk. From each area 20 boys and 20 girls in the age group of 3-5 years were selected randomly from 24 Anganwadi Kendras. Home environment inventory developed by Mohit (1990) was used to assess the home environment of children. The Socio-economic status scale developed by Aggarwal et al. (2005) was employed to assess the SES of the family. Results revealed that majority of pre-school children from urban group had good home and pre-school children from tribal and rural area had moderate home environment. Significant association was found between fathers' education and home environment among urban group pre-school children. Results also revealed a significant relationship between mothers' education and home environment of urban pre-school children.

How to cite this article : Nayak, V.S. and Pujar, L. (2019). A study on home environment among rural, tribal and urban pre-school children. Agric. Update, 14(1): 1-7; DOI : 10.15740/HAS/AU/14.1/1-7. Copyright@ 2019:

\section{Author for correspondence :}

\section{V.S. Nayak}

Department of Human

Development and

Family Studies, College of Community Science, University of Agricultural Sciences, Dharwad (Karnataka) India

Email:shiva.seetavijay10

@ gmail.com

See end of the article for

authors' affiliations 